\title{
Haematological changes in transhumant Baruwal sheep (Ovis aries) grazing in the western Himalayan mountains in Nepal
}

\author{
Shanker Raj Barsila ${ }^{1 *} \mathbb{D}$, Keshav Bhatt ${ }^{2}$, Badrika Devkota $^{3}$ and Naba Raj Devkota ${ }^{4}$
}

\begin{abstract}
Transhumance pastoralism is a traditional sheep management strategy adopted by the herders in the Himalayas to address environmental stress. The changes in haematological parameters in the transhumant sheep may well give insights of changes in physiological changes at pasture sites of various elevations in the transhumance cycle. For that purpose, 32 healthy Baruwal sheep were selected and divided into four groups: male (8) below 1 year, male (8) greater than 1 year, female (8) below 1 year, and female (8) greater than 1 year; the animals were selected based on similarity on body weight within the groups. The herd was clinically inspected for the presence of any infection. Adaptation period was set for 3 weeks at each pasture site. The blood samples were taken from designated groups at both grazing sites, i.e. from low (2431 m.a.s.l) to high stopover (3885 m.a.s.l) at the seventh day of the experimental period. Climatic data were recorded at both altitudes over the period of measurements from manually installed weather stations. Later, the herbage species were collected based on the visual sign of grazing at both sites and subjected to chemical composition analysis. The research results revealed that RBC (red blood cell), Hb (Haemoglobin), and PCV (packed cell volume) were significantly increased $(p<0.05)$ at high altitude, while MCH (mean corpuscular haemoglobin) and MCHC (Mean corpuscular haemoglobin concentration) were higher at low altitude. Sex and age had a similar effect $(p>0.05)$ on haematologic parameters, except for PCV and $\mathrm{MCH}$. The altitude had a big impact on leucocyte $(p<0.05)$, being greater at low altitude than high, which could be an indicator of the increased immunologic response at low altitude irrespective of age and sex. The research result revealed the changing haematological responses of Baruwal sheep to changing pasture sites at different altitudes in the transhumance movement. The results further gave a hint of the nutritional stress at low altitude when the herd arrives in the winter season. It is rather difficult to draw an immediate conclusion that pasture quality might be the contributory issue for a decline in the nutritional status of grazing sheep when the herbage species vary by altitude. The measurement of blood metabolic stressors could further facilitate description of the nutritional stress alongside the transhumance when the grazing species and quality are different. Strategic feed supplementation for a much better performance of Baruwal sheep is needed at low altitude to deal with the declined herbaceous quality during winter.
\end{abstract}

Keywords: Baruwal sheep, Transhumance, Haematology, Altitude, Himalayan mountains

\footnotetext{
* Correspondence: srbarsila@afu.edu.np

${ }^{1}$ Department of Animal Nutrition and Fodder Production, Agriculture and

Forestry University (AFU), Rampur, Chitwan, Nepal

Full list of author information is available at the end of the article
} 


\section{Background}

Transhumant sheep pastoralism is an important livestock system in the hills and mountains of Nepal, where sheep are raised principally for wool, meat, manure, and pack uses (Rauniyar et al. 2000). Baruwal sheep are amongst the vital native sheep breeds, being a multipurpose small ruminant kept in the transhumant pastoral system (Wilson 1997). Out of the national sheep population in Nepal, about $60 \%$ are reared under the transhumance system (LMP 1993). Summer grazing towards high altitude alpine pastures, and progressive downward movement through mixed forest areas and staying at open lands and crop aftermaths in winter is a characteristic feature of transhumance herding in Nepal (Parajuli et al. 2013). During such movement, there would be a modification in physiological and metabolic attributes that have an effect on the production efficiency of the flock.

The haematological examination of sheep is very important to appraisal of physiological changes appearing during the transhumance and is useful to manage and regulate management practices to optimize production efficiency of transhumant herds (Gupta et al. 2007; Opara et al. 2010). The haematological values of farm animals are influenced by age, sex, breed, climate, geographical location, season, day length, time of day, nutritional status, life habit of species, the present status of an individual, and other factors (Afolabi et al. 2011). Haematological studies facilitate understanding the response of blood constituents to the environment (Ovuru and Ekweozor 2004). They, in addition, help to determine the adaptation to high-altitude hypoxic environments (Barsila et al. 2014). The underlying genetic mechanisms of adaptation to high altitude (Qiu et al. 2012; Gorkhali et al. 2016) have been postulated in domestic animals. However, limited information is available regarding the physiological and metabolic performance in case of Baruwal sheep in Nepal. The present research had been designed to study the haematological profiles and their alteration due to changes in pasture sites at two elevational pasture sites along a transhumant route in the western Himalayan Mountains of Nepal.

\section{Study area}

The study was conducted in a transhumance route followed by most of the sheep flock in Khali (site A, high altitude) and Chandannath (site B, low altitude) of Jumla, Nepal (see in detail, Table 1). The area consisted of variously scattered rangelands along with mixed forest and mountain terrains ranging from 2000 to 4000 m.a.s.l (see Fig. 1) where Baruwal sheep were reared. The status and condition of the sheep flock were identified in consultation with the local District Livestock Services Office (DLSO) relating to the transhumance movement.

\section{Materials and methods \\ Climate data recording}

Meteorological data such as average temperature, rainfall, relative humidity, and wind velocity were collected from meteorological stations situated at Khali and Chandannath of Jumla respectively for the experimental duration of 1 month.

The detail of the study sites is presented in Table 1, and the transhumant migration pattern is shown in Fig. 1.

\section{Duration of study}

The study was conducted from July/August to November/ December 2017 to cover the two season (summer and winter) and two altitude ranges in an exceedingly wellused transhumant route of the herders. The adaptation period at each site was set at 21 days and the last 7 days were used for blood and sampling respectively.

\section{Animal selection}

The grazing route had approximately 45 flocks, and estimated sheep population was about 4,500 head (DLSO Jumla 2017), though grazing was in individual pasture sites. The study was carried out on a productive herd consisting of 80 Baruwal sheep. Thirty-two healthy

Table 1 Description of the pasture sites at two different altitudes selected for the experiment

\begin{tabular}{lll}
\hline Description & Site $\mathrm{A}^{\mathrm{a}}$ & Site $^{\mathrm{b}}$ \\
\hline Place & Khali & Chandannath \\
Location & $29^{\circ} 21^{\prime} 24.20^{\prime \prime} \mathrm{N}$ & $29^{\circ} 17^{\prime} 42.05^{\prime \prime} \mathrm{N}$ \\
& $82^{\circ} 12^{\prime} 21.56^{\prime \prime} \mathrm{E}$ & $82^{\circ} 10^{\prime} 56.06^{\prime \prime} \mathrm{E}$ \\
Altitude (m.a.s.l.) & $3885 \mathrm{~m}$ & $2431 \mathrm{~m}$ \\
Seasons of observation & Summer & Winter \\
Stay duration & April/May to Aug./Sept. & Sept./Oct. to March/April \\
Blood sampling & July 18, 2017 & Dec. 25, 2017 \\
Altitude category & High & Low \\
\hline
\end{tabular}

${ }^{\text {a }}$ Site $A$ is the highest stopover

${ }^{\mathrm{b}}$ Site $\mathrm{B}$ is the low-altitude stopover of the transhumant routes 


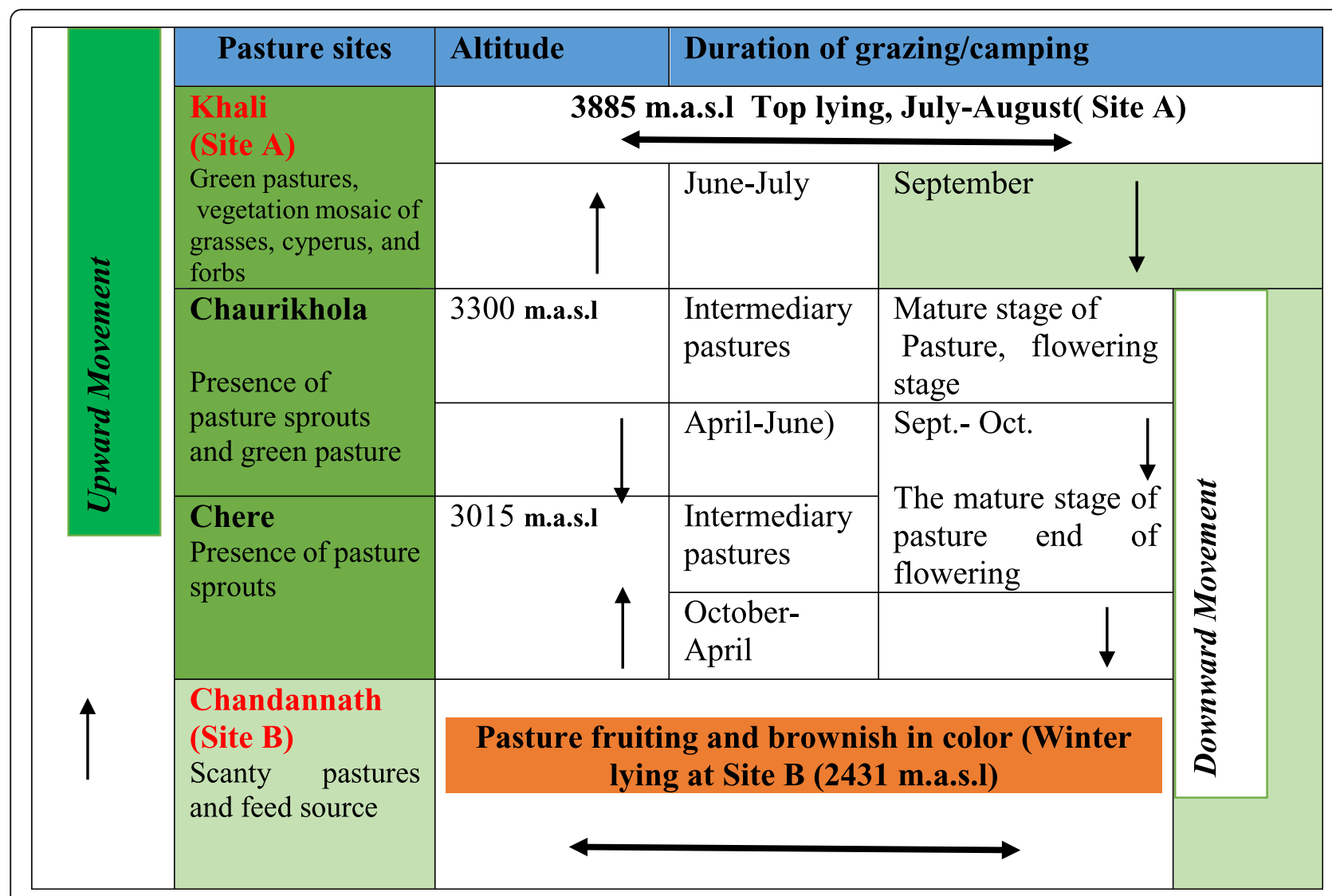

Fig. 1 The pattern of transhumance movement of sheep in the research site

sheep (16 rams and 16 ewes respectively by $<1$ year and $>1$ year age group) were selected based on similarity of body weight and lambing pattern within the respective groups. The details of the basis of the selection of Baruwal sheep for the experiment are presented in Table 2.

\section{Herd management}

Transhumance Baruwal sheep flock and the selected groups were drenched with locally available anthelminthic drugs (oxyclozanide) at the dose rate of $10 \mathrm{mg} /$ $\mathrm{kg}$ BW 1 month prior to collecting blood samples.

Before and once the experiment concluded, the selected sheep were kept together with the original sheep flock in the intermediary pastures (see Fig. 1).

\section{Vegetation sampling}

The topmost grazed herbage species were selected based on the visual sign of herbage removal by grazing sheep from both altitude sites respectively. Every 15 min was set to observe the herbage selection by every sheep, and the species grazed most frequently was hand-plucked, wellchopped and mixed for sun-drying respectively at both sites by a group of four observers without any bias. The observation was made for each of the last 7 days at each site, and the daily bulk samples were transferred to oven drying until they reached a constant weight. Then, prepared dried species samples were subjected to milling by passing through Thomas Mill at 45-mm mesh size and later subjected to laboratory analysis (AOAC 1997; Van Soest et al.

Table 2 Description of a selection of Baruwal sheep and their categories for the experiment

\begin{tabular}{lllll}
\hline Sex & Age group & Avg. age (months) & Body weight $(\mathrm{kg})^{\mathrm{a}}$ & Lambing pattern \\
\hline Ram & $<1$ year & 7 & $18 \pm 0.25$ & March-April \\
& $>1$ year & 14 & $28 \pm 0.33$ & July-Sept. \\
Ewe & $>1$ year & 7 & $17 \pm 0.21$ & Jan.-March \\
& $>1$ year & 14 & $25 \pm 0.15$ & Oct.-Nov.
\end{tabular}

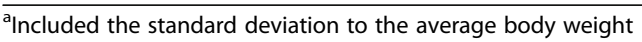


1991) at Animal Nutrition Lab of the Nepal Agricultural Research Council, Khumaltar, Lalitpur, Nepal.

\section{Blood sampling and analysis}

Prior to blood sampling, 21 days of grazing adaptation period was set in order to prevent the carry-over effect of the movement between the pastures. Blood was collected in the morning between 9 and 11 o'clock (at both pasture sites), before grazing, by puncturing the jugular vein. For the haematological analysis, blood was collected in 5-ml vacuum glass Vacutainer tubes coated with EDTA anticoagulant. Two blood samples per animal were collected on the 28th day and labelled clearly for analysis. After labelling, the samples were stored at $4{ }^{\circ} \mathrm{C}$ in the ice-box and transferred to Karnali Health Science Academy Hospital, Jumla district of Nepal, for further analysis of the haematologic parameters. Whole blood samples were analysed by Hematology Analyzer Elite 3 (Culter Counter, Erba, Germany) within three and half hours of blood sampling.

\section{Data analysis}

Analysis of data was done by using R version 3.5.2 ("Eggshell Igloo" Copyright (C) 2018, The R Foundation for Statistical Computing). The effect of site, sex, and age on haematological parameters was determined using a factorial model for three-factors which is given by:

$$
\begin{aligned}
& \mathbf{Y i j k} \mathbf{l}=\mu+\tau \mathbf{i}+\beta \mathbf{j}+\gamma \mathbf{k}+(\tau \beta) \mathbf{i} \mathbf{j}+(\tau \gamma) \mathbf{i k}+(\beta \gamma) \mathbf{j} \mathbf{k}+(\tau \beta \gamma) \mathbf{i j k}+\in \mathbf{i j k} \mathbf{k} \\
& \text { where: } \\
& Y i j k=\text { observational data } \\
& \mu=\text { overall mean } \\
& \tau i=\text { effect of } i \text { th level of factor site } \\
& \beta j=\text { effect of } j \text { th level of factor age } \\
& \gamma k=\text { effect of } k \text { th level of factor sex } \\
& (\tau \beta) i j=\text { interaction effect of factor site and age } \\
& (\tau \gamma) i k=\text { interaction effect of factor site and sex } \\
& (\beta \gamma) j k=\text { interaction effect of factor age and sex } \\
& (\tau \beta \gamma) i j k=\text { interaction effect of factor site, age, and sex }
\end{aligned}
$$

$$
\in i j k l=\text { random error }
$$

\section{Results \\ Climatic variables}

The average temperature measured in the high-altitude site (site A) was about $18{ }^{\circ} \mathrm{C}$, the humidity was about $70 \%$, and an average rainfall was $3.37 \mathrm{~mm}$ respectively. The temperature was found rather lower at the low altitude (site B) being about $8^{\circ} \mathrm{C}$, accompanied by a rather low humidity $(51 \%)$ and low rainfall $(0.05 \mathrm{~mm})$. Highaltitude site (site A) was rather humid (about 70\%) with rainfall (about $3.4 \mathrm{~mm}$ ). During the observation period in the low altitude (site B), mixed climate (open sky, frost, and rainfall on different days) occurred, but in the high altitude (site A) the sky was cloudy and rainfall accompanied in most of the time (Table 3).

\section{Herbage composition}

The results revealed that Kobresia nepalensis at high altitude and Poa alpina (about 212-220 g/ kg DM) at low altitude had rather higher CP content, and the least was found in Festuca sp. (about 139.4 g/kg DM) at low altitude. The range of EE content was about 2-4\% across the species. The results on neutral detergent fibre (NDF) showed the highest values obtained for Festuca sp. (700 g/ $\mathrm{kg}$ DM), followed by Potentilla peduncularis $(680 \mathrm{~g} / \mathrm{kg}$ DM) at low altitude. For other species, the NDF content remained in the range of $500-600 \mathrm{~g} / \mathrm{kg}$ DM at high altitude. Further, the acid detergent fibre (ADF) values were found

\begin{tabular}{|c|c|c|c|c|}
\hline \multirow[t]{2}{*}{ Variables } & \multicolumn{2}{|c|}{ Site $\mathrm{A}$ (high altitude) ${ }^{\mathrm{a}}$} & \multicolumn{2}{|c|}{ Site B (low altitude) ${ }^{b}$} \\
\hline & Mean \pm SD & Range & Mean \pm SD & Range \\
\hline$T_{\max }{ }^{\circ} \mathrm{C}$ & $24.52 \pm 2.52$ & $16.8-30.2$ & $17.95 \pm 2.83$ & $5.4-22.3$ \\
\hline$T_{\min },{ }^{\circ} \mathrm{C}$ & $11.91 \pm 4.33$ & $1.0-17.8$ & $-1.89 \pm 3.58$ & -8.7 to 5.6 \\
\hline Avg. temp., ${ }^{\circ} \mathrm{C}$ & $18.22 \pm 2.84$ & $9.65-23.90$ & $8.03 \pm 2.50$ & $2.75-13.45$ \\
\hline Avg. humidity, \% & $69.84 \pm 8.70$ & $44.1-89.7$ & $51.38 \pm 9.67$ & $38.5-83.1$ \\
\hline Avg. rainfall, mm & $3.37 \pm 6.52$ & $0.45-4.0$ & $0.05 \pm 0.32$ & $0-2.1$ \\
\hline Wind velocity, mph & $3.05 \pm 1.03$ & $0.5-5.1$ & $3.14 \pm 0.74$ & $2.75-13.45$ \\
\hline
\end{tabular}
highest in Potentilla peduncularis (about $589.6 \mathrm{~g} / \mathrm{kg} \mathrm{DM}$ ) at low altitude, and the highest ADL content was found in Kobresia nepalensis at high altitude (about $522 \mathrm{~g} / \mathrm{kg} \mathrm{DM}$ ) respectively. The details of the herbage chemical composition of the pasture sites are shown in Table 4.

\section{Haematological parameters \\ Red blood cells (RBC) count}

The altitude had a significant effect $(p<0.001)$ on RBC count of the sampled sheep, while age, sex, and their interactions had non-significant $(p>0.05)$ effect on RBC

Table 3 Climatic parameters at study sites (site A and site B)

aCloudy days in summer (15)

${ }^{b}$ Open sunny days (20) 
Table 4 Herbage chemical composition $(\mathrm{g} / \mathrm{kg}$ ) of herbages species at high-altitude grazing site during summer

\begin{tabular}{|c|c|c|c|c|c|c|c|c|c|}
\hline Herbage species & Functional group & $\mathrm{CP}$ & $\mathrm{EE}$ & NDF & ADF & $\mathrm{ADL}$ & Cellulose $^{d}$ & Hemicellulose $^{c}$ & Ash \\
\hline \multicolumn{10}{|l|}{$\overline{\text { Site A (High altitude) }}{ }^{a}$} \\
\hline Kobresia nepalensis & Cyperus & 219 & 39 & 610 & 522.11 & 160 & 362.11 & 87.89 & 90 \\
\hline Kobresia humilis & Cyperus & 198 & 28.5 & 540 & 388.23 & 82 & 306.23 & 151.77 & 110 \\
\hline Carex sp. & Cyperus & 192 & 26 & 684 & 536.21 & 125.5 & 410.71 & 147.79 & 90.7 \\
\hline Selinum tenuifolium & Forb & 192.1 & 33 & 507 & 430.25 & 195 & 235.25 & 76.75 & 90.8 \\
\hline Ranunculus heterophyllus & Forb & 193 & 27 & 550 & 476.26 & 195 & 281.26 & 73.74 & 100.1 \\
\hline Potentilla sp. & Forb & 179 & 33 & 498 & 452.21 & 237 & 215.21 & 45.79 & 79 \\
\hline \multicolumn{10}{|l|}{ Site B (Low altitude) ${ }^{b}$} \\
\hline Poa alpina & Grass & 212.3 & 31.5 & 603 & 360.15 & 88 & 272.15 & 242.85 & 100 \\
\hline Plantago major & Forb & 181 & 34 & 502 & 429.2 & 195 & 234.2 & 72.8 & 103 \\
\hline Potentilla peduncularis & Forb & 143.1 & 28 & 680 & 589.6 & 109.2 & 480.4 & 90.4 & 98 \\
\hline Festuca sp. & Grass & 139.4 & 23 & 700 & 530.13 & 114.4 & 415.73 & 169.87 & 84 \\
\hline
\end{tabular}

${ }^{\text {a }}$ Species listed more than $10 \%$ coverage only

${ }^{\mathrm{b}}$ The dead and withered species not selected for chemical analysis

${ }^{\mathrm{C}}$ Hemicellulose $=$ NDF-ADF

${ }^{\mathrm{d}}$ Cellulose $=\mathrm{ADF}-\mathrm{ADL}$

value (Tables 5 and 6). The maximum value of $R B C$ observed was $11.48 \times 10^{6} / \mu \mathrm{L}$ in females below 1 year age at the high site which was par with females above 1 year age $\left(9.75 \times 10^{6} / \mu \mathrm{L}\right)$ and males below 1 year age $\left(10.05 \times 10^{6} /\right.$ $\mu \mathrm{L})$ at the high site, while minimum value observed was $5.34 \times 10^{6} / \mu \mathrm{L}$ in males and females above 1 year age at lower altitude which was par with females below 1 year $\left(6.46 \times 10^{6} / \mu \mathrm{L}\right)$ and males below 1 year of age $\left(6.15 \times 10^{6} /\right.$ $\mu \mathrm{L})$ at the low site. The range of RBC count was found between 5 and $11 \times 10^{6} / \mu \mathrm{l}$. The detailed values of RBC count on high and low altitudes for rams and ewes of two age groups are presented in Tables 5 and 6.

\section{White blood cells (WBC) count}

The altitude had a significant effect on WBC count $(p<$ 0.001 ), while age, sex, and their interaction have no significant effect on WBC value (Tables 5 and 6). WBC was found significantly increasing at a low altitude. The maximum value of WBC observed was $11.85 \times 10^{3} / \mu \mathrm{l}$ in females above 1 year age at the lower site which was par with males below 1 year age $\left(10.29 \times 10^{3} / \mu \mathrm{L}\right)$, males above 1 year
$(10.40 \times 103 / \mu \mathrm{L})$, and females below 1 year $\left(10.16 \times 10^{3} / \mu \mathrm{L}\right)$ at a lower altitude. While minimum value observed was $5.16 \times 10^{3} / \mu \mathrm{L}$ in females above 1 year at a higher altitude which was par with males below 1 year $\left(6.78 \times 10^{3} / \mu \mathrm{L}\right)$, males above 1 year $\left(5.66 \times 10^{3} / \mu \mathrm{L}\right)$, and females below 1 year $\left(7.66 \times 10^{3} / \mu \mathrm{L}\right)$ at the low site. The range of WBC count was found between 5 and $12 \times 10^{3} / \mu \mathrm{l}$. The site, age, sex, and respective interaction had no significant effect on lymphocyte, monocyte, and granulocyte percentage (see Tables 5 and 6).

\section{Haemoglobin $(\mathrm{Hb})$}

The altitude was found to have a significant effect on haemoglobin $(\mathrm{Hb})$ level $(p<0.001)$, while age, sex, and their interaction had no significant effect on haemoglobin. The maximum value of $\mathrm{Hb}$ observed was $17.53 \mathrm{~g} / \mathrm{dl}$ in females below 1 year age at the high site which was at par with males below 1 year $(17.05 \mathrm{~g} / \mathrm{dl})$ at the high altitude, while minimum value observed was $12.13 \mathrm{~g} / \mathrm{dl}$ in females below 1 year age at lower altitude which was par with $\mathrm{Hb}$ value of males below and above 1 year $(12.88 \mathrm{~g} / \mathrm{dl}$ and $12.92 \mathrm{~g} / \mathrm{dl})$

Table 5 Haematological values of transhumance Baruwal sheep

\begin{tabular}{|c|c|c|c|c|c|c|c|c|c|}
\hline \multirow[t]{3}{*}{ Parameters } & \multicolumn{4}{|c|}{ High altitude } & \multicolumn{4}{|c|}{ Low altitude } & \multirow[t]{3}{*}{ SEM } \\
\hline & \multicolumn{2}{|l|}{ Male } & \multicolumn{2}{|l|}{ Female } & \multicolumn{2}{|l|}{ Male } & \multicolumn{2}{|l|}{ Female } & \\
\hline & $<1$ year & $>1$ year & $<1$ year & $>1$ year & $<1$ year & $>1$ year & $<1$ year & $>1$ year & \\
\hline $\mathrm{RBC} \times 10^{6} / \mu \mathrm{l}$ & $10.05^{\mathrm{ab}}$ & $9.00^{\mathrm{abc}}$ & $11.48^{\mathrm{a}}$ & $9.75^{\mathrm{ab}}$ & $6.15^{b c}$ & $5.34^{c}$ & $6.46^{\mathrm{bc}}$ & $5.34^{c}$ & 0.51 \\
\hline $\mathrm{WBC} \times 10^{3} / \mu \mathrm{l}$ & $6.78^{c}$ & $5.66^{c}$ & $7.66^{b c}$ & $5.16^{c}$ & $10.29^{\mathrm{ab}}$ & $10.40^{\mathrm{ab}}$ & $10.16^{\mathrm{ab}}$ & $11.85^{\mathrm{a}}$ & 0.43 \\
\hline Lym\% & $56.50^{\mathrm{a}}$ & $60.74^{a}$ & $67.31^{\mathrm{a}}$ & $64.70^{\mathrm{a}}$ & $61.15^{\mathrm{a}}$ & $72.10^{\mathrm{a}}$ & $58.06^{a}$ & $71.30^{\mathrm{a}}$ & 2.16 \\
\hline Mid\% & $18.46^{\mathrm{ab}}$ & $19.06^{\mathrm{ab}}$ & $15.80^{\mathrm{ab}}$ & $17.50^{\mathrm{ab}}$ & $21.76^{\mathrm{a}}$ & $13.08^{b}$ & $18.75^{\mathrm{ab}}$ & $19.90^{\mathrm{ab}}$ & 0.86 \\
\hline Gra\% & $25.03^{\mathrm{a}}$ & $20.22^{\mathrm{a}}$ & $16.80^{\mathrm{a}}$ & $17.75^{\mathrm{a}}$ & $17.33^{\mathrm{a}}$ & $14.62^{\mathrm{a}}$ & $23.55^{\mathrm{a}}$ & $8.80^{\mathrm{a}}$ & 1.74 \\
\hline
\end{tabular}

Superscript roman letters a-c in the same row indicated significant differences $(p<0.05)$ between altitude $\times$ age $\times$ sex interaction means according to the statistical model 
Table $6 P$ value of the haematological value in accordance with the site, age, sex, and their interactions

\begin{tabular}{|c|c|c|c|c|c|c|c|}
\hline \multirow[t]{2}{*}{ Parameters } & \multicolumn{7}{|l|}{$P$ value } \\
\hline & Altitude & Age & Sex & Altitude $\times$ age & Altitude $\times$ sex & Age $\times$ sex & Altitude $\times$ age $\times$ se $x$ \\
\hline $\mathrm{RBC} \times 10^{6} / \mu \mathrm{l}$ & $<0.001$ & 0.183 & 0.409 & 0.775 & 0.565 & 0.797 & 0.923 \\
\hline $\mathrm{WBC} \times 10^{3} / \mu \mathrm{l}$ & $<0.001$ & 0.451 & 0.556 & 0.119 & 0.918 & 0.951 & 0.331 \\
\hline Lym\% & 0.580 & 0.180 & 0.490 & 0.230 & 0.229 & 0.820 & 0.650 \\
\hline Mid\% & 0.590 & 0.250 & 0.490 & 0.068 & 0.536 & 0.163 & 0.266 \\
\hline Gra\% & 0.361 & 0.239 & 0.594 & 0.515 & 0.228 & 0.705 & 0.285 \\
\hline
\end{tabular}

respectively at lower altitude. The range of haemoglobin count was found between 12 and $17 \mathrm{~g} / \mathrm{dl}$ across the pasture site and sex of sheep (see Tables 7 and 8 ).

\section{Packed cell volume (PCV)/haematocrit (HCT)}

Altitude and age was found to have a significant effect on HCT\% ( $p<0.001$ and $p<0.05$ respectively), while sex and respective interactions have been found to have no significant effect on HCT\% $(p>0.05)$. A significant increase in HCT\% was found at the high altitude site as compared to the lower altitude site. Maximum HCT\% was $40.68 \%$ found in females below 1 year age at the higher site which was par with males below and above 1 year age $(39.49 \%, 34.64 \%)$ respectively and $31.59 \%$ in females above 1 year at the high site. Minimum $20.67 \%$ was observed in males above 1 year age at the lower site which was par with male below 1 year $23.52 \%$, females below and above 1 year $(23.12 \%$ and $21.18 \%)$ respectively at a lower altitude. Haematocrit values were observed to range from 21 to $41 \%$ (see Tables 7 and 8).

\section{Mean corpuscle volume (MPV) and mean corpuscular haemoglobin $(\mathrm{MCH})$ value}

Altitude, age, sex, and their respective interaction had no significant effect on MPV value $(p>0.05$; details in Tables 7 and 8). The site and age had a significant effect on $\mathrm{MCH}$ value $(p<0.05)$ respectively, while sex and respective interactions have been found to have no significant effect on $\mathrm{MCH}$ value $(p>0.05)$. A significant increase in $\mathrm{MCH}$ value was observed at the low altitude pasture site as compared to the high site. Maximum $\mathrm{MCH}$ value observed was $24.16 \mathrm{pg}$ in males above 1 year age at low altitude which was par with females below and above 1 year age $(21.25 \mathrm{pg}$ and $24.10 \mathrm{pg})$ and males below 1 year $22.05 \mathrm{pg}$ at low site, and minimum value was $16.8 \mathrm{pg}$ in females below 1 year at high site which was par with males below and above 1 year $(7.62 \mathrm{pg}$ and $18.14 \mathrm{pg})$ respectively and females above 1 year $(17.2 \mathrm{pg})$ at high site. $\mathrm{MCH}$ value observed was found to vary from 17 to $24 \mathrm{pg}$.

\section{Mean corpuscular haemoglobin concentration (MCHC) value}

The altitude was found to have a significant effect on MCHC value $(p<0.001)$, while age, sex, and respective interactions were found to have no significant effect on $\mathrm{MCHC}$ value $(p>0.05)$. A significant increase in $\mathrm{MCHC}$ value was observed at the low altitude site as compared to the high altitude site. Maximum $\mathrm{MCHC}$ value observed was $62.32 \mathrm{~g} / \mathrm{dl}$ in males above 1 year age at lower site which was par with females below and above 1 year age (58.65 g/ $\mathrm{dl}$ and $60.75 \mathrm{~g} / \mathrm{dl}$ ) respectively at lower site and $44.03 \mathrm{~g} / \mathrm{dl}$ in females below 1 year at high site which was par with males below and above 1 year $(43.92 \mathrm{~g} / \mathrm{dl}$ and $45.72 \mathrm{~g} / \mathrm{dl})$ respectively at high site. The range of $\mathrm{MCHC}$ values observed was between 44 and $61 \mathrm{~g} / \mathrm{dl}$ (see Tables 7 and 8).

\section{Mean platelet volume (MPV)}

The altitude was found to have a significant effect on MPV value $(p<0.001)$, while age, sex, and respective interactions were found to have no significant effect on

Table 7 The erythrocyte parameters in accordance with the site, age, sex, and their interactions

\begin{tabular}{|c|c|c|c|c|c|c|c|c|c|}
\hline \multirow[t]{3}{*}{ Parameters } & \multicolumn{4}{|c|}{ High altitude } & \multicolumn{4}{|c|}{ Low altitude } & \multirow[t]{3}{*}{ SEM } \\
\hline & \multicolumn{2}{|l|}{ Male } & \multicolumn{2}{|l|}{ Female } & \multicolumn{2}{|l|}{ Male } & \multicolumn{2}{|l|}{ Female } & \\
\hline & $<1$ year & $>1$ year & $<1$ year & $>1$ year & $<1$ year & $>1$ year & $<1$ year & $>1$ year & \\
\hline $\mathrm{Hb}, \mathrm{g} / \mathrm{dl}$ & $17.05^{a b}$ & $15.68^{\mathrm{abc}}$ & $17.53^{a}$ & $14.45^{\mathrm{bcd}}$ & $12.88^{\mathrm{cd}}$ & $12.92^{\mathrm{cd}}$ & $12.13^{d}$ & $14.35^{\mathrm{bcd}}$ & 0.43 \\
\hline $\mathrm{HCT} / \mathrm{PCV}, \%$ & $39.49^{a}$ & $34.64^{a}$ & $40.68^{a}$ & $31.59^{a b}$ & $23.52^{b c}$ & $20.67^{c}$ & $23.12^{b c}$ & $21.18^{b c}$ & 1.56 \\
\hline MCV, \% & $39.87^{a}$ & $39.20^{a}$ & $37.30^{a}$ & $34.50^{a}$ & $38.87^{a}$ & $39.40^{a}$ & $38.50^{a}$ & $39.50^{a}$ & 0.62 \\
\hline $\mathrm{MCH}, \mathrm{pg}$ & $17.62^{\mathrm{ab}}$ & $18.14^{\mathrm{ab}}$ & $16.80^{a}$ & $17.20^{\mathrm{ab}}$ & $22.05^{a b}$ & $24.16^{a}$ & $21.25^{a b}$ & $24.10^{\mathrm{a}}$ & 0.73 \\
\hline $\mathrm{MCHC}, \mathrm{g} / \mathrm{dl}$ & $43.93^{d}$ & $45.72 c^{d}$ & $44.03^{d}$ & $47.70^{\mathrm{bcd}}$ & $56.58^{a b c}$ & $62.32^{a}$ & $58.65^{a b}$ & $60.75^{a}$ & 1.55 \\
\hline$M P V, f l$ & $15.92^{\mathrm{a}}$ & $16.88^{a}$ & $14.51^{\mathrm{a}}$ & $11.45^{a}$ & $17.66^{\mathrm{a}}$ & $18.88^{a}$ & $16.21^{a}$ & $19.70^{a}$ & 0.83 \\
\hline
\end{tabular}

SEM standard error of the mean

Superscript roman letters a-d in the same row indicated significant differences $(p<0.05)$ between altitude $\times$ age $\times$ sex interaction means according to the statistical model 
Table 8 -value of the erythrocyte parameters in accordance with site, age, sex, and their interactions

\begin{tabular}{|c|c|c|c|c|c|c|c|}
\hline Parameters & Altitude & Age & Sex & Altitude $\times$ age & Altitude $\times$ sex & Age $\times$ sex & Altitude $\times$ age $\times$ sex \\
\hline $\mathrm{Hb}, \mathrm{g} / \mathrm{dl}$ & $<0.001$ & 0.389 & 0.920 & 0.0517 & 0.945 & 0.871 & 0.184 \\
\hline $\mathrm{HCT} / \mathrm{PCV}, \%$ & $<0.001$ & $<0.05$ & 0.964 & 0.3971 & 0.9858 & 0.721 & 0.582 \\
\hline$M C V, \%$ & 0.716 & 0.939 & 0.216 & 0.555 & 0.284 & 0.778 & 0.66 \\
\hline $\mathrm{MCH}, \mathrm{pg}$ & $<0.001$ & $<0.05$ & 0.964 & 0.397 & 0.986 & 0.721 & 0.582 \\
\hline $\mathrm{MCHC}, \mathrm{g} / \mathrm{dl}$ & $<0.001$ & 0.180 & 0.734 & 0.672 & 0.943 & 0.869 & 0.604 \\
\hline$M P V, f l$ & $<0.001$ & 0.451 & 0.556 & 0.119 & 0.918 & 0.951 & 0.331 \\
\hline
\end{tabular}

MPV value $(p>0.05)$. A significant increase in MPV value was observed at the low altitude as compared to the high site. Maximum MPV value observed was $19.7 \mathrm{fl}$ in females above 1 year age at the lower site which was par with males below and above 1 year age $(17.66 \mathrm{fl}$ and $16.88 \mathrm{fl})$ respectively and females below 1 year $(18.88 \mathrm{fl})$ at the low site. Minimum value observed was $11.45 \mathrm{fl}$ in females below 1 year at the high site which was par with males below and above 1 year $(15.92 \mathrm{fl}$ and $16.88 \mathrm{fl})$ respectively and 14.51. The range of MPV values observed was between 12 and $20 \mathrm{fl}$ (Tables 7 and 8).

\section{Discussion}

The haematological measures in the present study are indicative of the nutritional stress and provide a hint for future studies. Measuring the haematological attributes may well be less time-consuming and less costly than any other nutritional assessments in the sheep herd, and that could be even applicable to the transhumance system. As sheep are grazing across the elevational gradient, frequent measures of such attributes might facilitate in balancing the feeds and nutritional status of different physiological stages of animals and for different purposes that further might acknowledge the standards of feed and nutrition management regime (traditional transhumance or modern stall feeding).

Transhumance is an extensive system of livestock farming. Animals under such extensive care might expend more energy for physical and ranging activities, compared to animals having a sedentary life under intensive management which may expend less. Sheep and goats managed under traditional husbandry practices have low haematological values compared to modern husbandry practices, regardless of age, sex, and climate (Coles 1986). So therefore, haematological analyses may be indicative for maintaining the leastcost based production for traditionally farmed or herded sheep in the Himalayan landscapes. Blood is an important index of physiological and pathological changes in an organism (Mitruka and Rawnsley 1977). The examination of blood gives the opportunity to investigate the presence of several metabolites and other constituents within the body of animals, and blood plays a significant role within the physiological, nutrition-associated pathological standing of an organism (Aderemi 2004). Haematology and serum biochemistry assay of livestock determines the physiological disposition of the animals to their nutrition (Menon et al. 2013). Deficiency of both macro- and micro-nutrients triggers enormous discrepancies in haematological and serum biochemical profiles of livestock animals (Onasanya et al. 2015). Data in the present study has clearly demonstrated that changes in nutritional quality in the pasture had an impact on blood haematological profile, and such a trend had also been reported by Šoch et al. (2011). However, it was obvious that the pasture species were different due to altitudinal variations. Furthermore, the altitude causes immune suppressions in sheep (Meehan 1987), which is, however, observed at low altitude (increased WBC count) because of a decline in herbaceous quality. The measurement of other metabolic stressors has to be considered in future when the pasture species varies with the elevational pasture sites, as was the case in the present study.

\section{Erythrocyte parameters}

The haemoglobin $(\mathrm{Hb})$ plays a very important role in physiological adjustment to cope with hypoxic environments at high altitude (Coles 1986), while the poorer herb quality and the difference in herbage species may induce low $\mathrm{Hb} /$ RBC at low altitude sites. Likewise, lower PCV values at low grazing altitudes indicated that the flock was vulnerable to anaemic conditions, and such trends had been previously reported in several experiments. The increased tendency of blood erythrocytes in domestic cattle at high altitude is a commonly reported phenomenon (Hays et al. 1978). In the present study, the high $\mathrm{RBC}$ values were observed at higher altitude. An increased number of RBC in sheep when the animals were exposed to a higher altitude seems the most important haematological acclimatization's response reported to a low oxygen environment (Monge and Leon-Velarde 1991; Weber 2007). RBC count significantly increased at a higher altitude due to the erythropoiesis process; such trends had also been observed (Al-Samarai and Al-Jbory 2017) in Iraqi Awassi sheep. At high altitude, an increase in RBC and a decrease in MCV occurred at the same time in the total count; therefore, the total surface of $\mathrm{RBC}$ was enlarged, which was advantageous for $\mathrm{Hb}$ to bind oxygen (Bunn 1980). Therefore, the increase in RBC and also the decrease in MCV are also the common 
haematologic mechanisms for mammals and birds to adapt to high-altitude hypoxia (Wu et al. 2005).

A decrease in lymphocytes with increasing age and an increase in neutrophils with decreasing age, which were determined in sheep, could be related to the immune response at the advancing stage of age. The contrasting result might be due to the nutritional status, geography, and seasonal and meteorological variations in the grazing sites respectively. Age and site were found to have a significant effect on haematocrit and mean corpuscular $\mathrm{Hb}$ levels. HCT and $\mathrm{MCH}$ levels observed were higher in animals below 1 year age when compared to an adult. An identical result was illustrated by Egbe-Nwiyi et al. (2000) in Nigeria where he observed high HCT and $\mathrm{MCH}$ level in 0 to 6 months of sheep than an adult.

In the present study, $\mathrm{Hb}$ level and haematocrit values were found to be increased significantly at a high altitude, and such trends in domestic cattle had been reported by Zemp et al. (1989). Previous researchers had additionally concluded that an increase in $\mathrm{RBC}, \mathrm{Hb}$, and haematocrit percentage is a compensatory mechanism of reduced oxygen saturation at high altitude (Yersin et al. 1992). Further, it was also reported that $\mathrm{Hb}$ with high oxygen affinities in high altitude species occur more than those of low land relatives (Storz 2007); Baruwal sheep might have gained such high-altitude adaptation characteristics. Hypoxic condition at high altitudes regulates partial pressure of oxygen in arteries that alters the physiological phenomenon either by changing $\mathrm{Hb}$ concentration in blood or by changing the oxygen-binding affinity of $\mathrm{Hb}$ (Storz and Moriyama 2008; Storz 2016). The former mechanism is more important in acclimatization response of low land natives, and the latter one is more important in genetically hypoxia-adapted high land natives (Bunn 1980). Higher values of RBC, Hb, and haematocrit levels indicated the response mechanism of Baruwal sheep in response to hypoxic conditions at high altitude, that helps to improve oxygen delivery capacity. Further, the higher values might be indicative of the abundance and availability of the better quality pasture species at high altitude. Lower RBC, $\mathrm{Hb}, \mathrm{HCT}$, and PCV values at the low altitude could also be due to the unavailability of essential minerals in the diet, due to the scanty and lower herbage availability during the winter season. Low concentration of blood macro-minerals during winter in Tibet had been also reported by Xin et al. (2011). As a mechanism of high altitude adaptation, the increase of $\mathrm{Hb}$ concentration in blood at high altitude has been repeatedly reported in other domestic species such as in cattle (Zemp et al. 1989) and yaks and their hybrids with cattle (Barsila et al. 2014).

\section{Leucocyte parameters}

Acute stress during the adaptation period at higher altitude can increase stress hormone level, but while persistently living at the thermo-comfortable environment at the higher site with relatively high humidity, an abundance of quality forage and fodder after the acclimatization phase may normalize the WBC (white blood cell) values at higher altitude. Meanwhile, various factors such as colder environment, low humidity, nutritional deficiencies, and unavailability of feed resources during winter at low altitude increase cortical level, thereby increasing leukocyte values at low altitude as compared to high grazing site in transhumance Baruwal sheep.

In the present study, the leukocyte level was found significant with changing altitude. The higher leucocyte values at low altitude grazing sites might be the indication of nutritional and environmental immune suppression, as the pasture condition was completely brownish and withered. It has been reported that WBC are at lower levels in different breeds of cattle throughout summer compared to spring (Mirzadeh et al. 2010).

In the present study, greater values of leukocytes in the lower site during winter as compared to higher altitude may be due to the stress imposed on transhumance sheep. The stress hormones, particularly cortisol and adrenaline, enhance the rise in WBC count and exert differential effects on leukocyte counts (Cupps and Fauci 1982). Acute stressors, e.g. cold stress, and the poor nutritional status might activate the hypothalamic-pituitary-adrenal axis, resulting in increased cortisol levels (Dantzer and Mormède 1983). Experiments conducted earlier additionally found an explicit increment in cortisol level in an animal exposed to cold stress due to lipolysis and utilization of brown adipose tissue for maintenance of body heat (Himms-Hagen 1990).

The pathological causes of changes in MPV values were not shown in the present study; however, greater MPV values at low altitude indicated grazing on thorny vegetation or some reasonably physical pain in sheep during the herbage selection. Likewise, the decreased MPV at high altitude in summer would be a reflection of relatively tender vegetation available for grazing.

\section{Conclusions}

Haematological alterations at two pasture sites at different altitudes during transhumance revealed a physiological adaptation mechanism of Baruwal sheep in the Himalayas. The nutritional stress imposed on sheep during transhumance has been hinted at by the haematological parameters. Furthermore, the greater leucocyte count at low altitude needs to be considered in terms of adaptive and slower downward herd movement. Strategic feed supplements are needed during stays at a low altitude, once the pasture condition is different and poor in quality, compared to pasture at high altitude. The measure of blood metabolic stressors in future studies may further facilitate explanations of nutritional stress, once pasture species and quality are different during the transhumance movement of sheep. 


\section{Abbreviations}

ADF: Acid detergent fibre; ADL: Acid detergent lignin; BW: Body weight; CF: Crude fibre; CP: Crude protein; DLSO: District Livestock Services Office; DM: Dry matter; EE: Ether extract; Gran: Granulocytes; Hb: Haemoglobin; HCT: Haematocrit; Leuc: Leucocytes; Lym: Lymphocyte; MCH: Mean corpuscular haemoglobin; MCHC: Mean corpuscular haemoglobin concentration; MCV: Mean corpuscle volume; Mid: Percentage number of precursor white cells; MPV: Mean platelet volume; NDF: Neutral detergent fibre; PCV: Packed cell volume; RBC: Red blood cell; $T_{\text {max }}$ : Maximum temperature; $T_{\min }$ : Minimum temperature; WBC: White blood cells

\section{Acknowledgements}

The authors are thankful for the support provided by the local sheepherders, District Livestock Services Office (DLSO), and Karnali Academy of Health Sciences/District hospital of Jumla district of Nepal for providing support during the field and lab works.

\section{Authors' contributions}

SRB conceived the study, participated in designing and conducting the field works, carried out lab works, and helped in the preparation of the manuscript. KB carried out the field and lab works and was involved in the manuscript preparation. BD carried out the data analysis. NRD participated in the revision of the manuscript. All the authors read and approved the final manuscript.

\section{Funding}

The project was funded by the Nepal Academy of Science and Technology (NAST) as a Faculty Grant, and the field travel cost was further supported by the Directorate of Research and Extension Office of the Agriculture and Forestry University, Nepal.

\section{Availability of data and materials}

The datasets used and/or analysed during the current study are available from the corresponding author on reasonable request.

\section{Ethics approva}

Animals used in the experiments were duly permitted from the herders for the study purpose.

Nepal has no established system for ethical approval of animal experiments. Ethical principles were taken into account to adhere to the national and international standards while conducting the experiment. All the processes involving animals followed the international guiding principles listed by the Council for International Organizations of Medical Sciences and the International Council for Laboratory Animals (2012)

\section{Consent for publication}

Not applicable.

\section{Competing interests}

The authors declare that they have no competing interests.

\section{Author details}

'Department of Animal Nutrition and Fodder Production, Agriculture and Forestry University (AFU), Rampur, Chitwan, Nepal. ${ }^{2}$ Department of Livestock Services, Ministry of Agricultural and Livestock Development, World Bank/ Nepal Livestock Sector Innovation Project, Hariharbhawan, Lalitpur, Nepal. ${ }^{3}$ Multidimensional Action for Development Nepal (MADE Nepal), Bharatpur Metropolitan City-19, Sharadpur, Chitwan, Nepal. ${ }^{4}$ Directorate of Research and Extension (DOREX), Agriculture and Forestry University (AFU), Rampur, Chitwan, Nepal.

Received: 21 June 2019 Accepted: 25 November 2019

Published online: 26 February 2020

\section{References}

Aderemi, F.A. 2004. Effects of replacement of wheat bran with cassava root sieviate supplemented or unsupplemented with enzyme on the haematology and serum biochemistry of pullet chicks. Tropical Journal of Animal Science 7 (1): 147-153.
Afolabi, K.D., A.O. Akinsoyinu, A.R. Abdullah, R. Olajide, and S.B. Akinleye. 2011 Haematological parameters of the Nigerian local grower chickens fed varying dietary levels of palm kernel cake. Poljoprivreda 17 (1): 74-78.

Al-Samarai, F.R., and W.A. Al-Jbory. 2017. Effect of some environmental factors on hematological parameters in apparently healthy Iraqi Awassi sheep. Journal of Entomology and Zoology Studies 5 (3): 1668-1671.

AOAC. 1997. Official methods of analysis. Association of Official Analysis of Chemists, Arlington, VA, USA.

Barsila, S.R., M. Kreuzer, N.R. Devkota, L. Ding, and S. Marquardt. 2014. Adaptation to Himalayan high altitude pasture sites by yaks and different types of hybrids of yaks with cattle. Livestock Science 169: 125-136 https://doi.org/10. 1016/j.livsci.2014.09.004.

Bunn, H.F. 1980. Regulation of hemoglobin function in mammals. American Zoologist. 20 (1): 199-211 https://doi.org/10.1093/icb/20.1.199.

Coles, E.H. 1986. Veterinary clinical pathology. Vol. 986. 4th ed, 136-170. Philadelphia, London, Toronto, Mexico, Riodejenario, Sydney, Tokyo \& Hong Kong: WB Saunders Company.

Cupps, T.R., and A.S. Fauci. 1982. Corticosteroid-mediated immunoregulation in man. Immunological Reviews 65 (1): 133-155 https://doi.org/10.1111/j.1600065X.1982.tb00431.X.

Dantzer, $R$, and P. Mormède. 1983. Stress in farm animals: A need for reevaluation. Journal of Animal Science 57 (1): 6-18 https://doi.org/10.2527/jas1983.5716.

DLSO. 2017. Annual report. District Livestock Services Office, Jumla, Nepal.

Egbe-Nwiyi, T.N., S.C. Nwaosu, and H.A. Salami. 2000. Haematological values of appararently healthy sheep and goats as influenced by age and sex in arid zone of Nigeria. African Journal of Biomedical Research 3 (2): 109-115.

Gorkhali, N.A., K. Dong, M. Yang, S. Song, A. Kader, B.S. Shrestha, X. He, Q. Zhao, Y. Pu, X. Li, J. Kijas, W. Guan, J. Han, L. Jiang, and Y. Ma. 2016. Genomic analysis identified a potential novel molecular mechanism for high-altitude adaptation in sheep at the Himalayas. Scientific Reports 6: 29963. https://doi. org/10.1038/srep29963

Gupta, A.R., R.C. Patra, M. Saini, and D. Swarup. 2007. Haematology and serum biochemistry of chital (Axis axis) and barking deer (Muntiacus muntjak) reared in semi-captivity. Veterinary Research Communications 31 (7): 801-808 https:// doi.org/10.1007/s11259-006-0095-8.

Hays, F.L., W. Bianca, and F. Näf. 1978. Effects of exposure to a simulated altitude of 3,500 m on calves and oxen. International Journal of Biometeorology 22 (2): 135-146 https://doi.org/10.1007/BF01552894

Himms-Hagen, J. 1990. Brown adipose tissue thermogenesis: Role in thermoregulation, energy regulation and obesity. In Thermoregulation: Physiology and Biochemistry, 327-414.

LMP (Livestock Master Plan). 1993. Ministry of Agriculture and Cooperatives, Singhdurbar, Kathmandu, Nepal.10.1186/s13570-019-0156-6

Meehan, R.T. 1987. Immune suppression at high altitude. Annals of Emergency Medicine 16 (9): 974-979 https://doi.org/10.1016/S0196-0644(87)80743-6.

Menon, D.G., D.C. Bennett, A.M. Schaefer, and K.M. Cheng. 2013. Hematological and serum biochemical profile of farm emus (Dromaius novaehollandiae) at the onset of their breeding season. Poultry Science 92 (4): 935-944 https:// doi.org/10.3382/ps.2012-02870.

Mirzadeh, K.H., S. Tabatabaei, M. Bojarpour, and M. Mamoei. 2010. Comparative study of hematological parameters according strain, age, sex, physiological status and season in Iranian cattle. Journal of Animal and Veterinary Advances 9 (16): 2123-2127.

Mitruka, B.M., and H.M. Rawnsley. 1977. Clinical biochemical and hematological reference values in normal experimental animals, 134-135. USA: Masson Publishing Inc.

Monge, C., and F. Leon-Velarde. 1991. Physiological adaptation to high altitude: Oxygen transport in mammals and birds. Physiological Reviews 71 (4): 11351172 https://doi.org/10.1152/physrev.1991.71.4.1135.

Onasanya, G.O., F.O. Oke, T.M. Sanni, and A.I. Muhammad. 2015. Parameters influencing haematological, serum and bio-chemical references in livestock animals under different management systems. Open Journal of Veterinary Medicine 5 (8): 181. https://doi.org/10.4236/ojvm.2015.58025.

Opara, M.N., N. Udevi, and I.C. Okoli. 2010. Haematological parameters and blood chemistry of apparently healthy West African Dwarf (Wad) goats in Owerri, South Eastern Nigeria. New York Science Journal 3 (8): 68-72.

Ovuru, S.S., and I.K.E. Ekweozor. 2004. Haematological changes associated with crude oil ingestion in experimental rabbits. African Journal of Biotechnology 3 (6): 346-348 https://doi.org/10.5897/AJB2004.000-2064.

Parajuli, D.P., L.N. Paudel, and R. Gyawali. 2013. Changes in pastoral production systems in high-altitude village-rangeland interfaces in Nepal. In High-altitude rangelands and their interfaces in the Hindu Kush Himalayas, 48-54. 
Qiu, Q., G. Zhang, T. Ma, W. Qian, J. Wang, Z. Ye, C. Cao, Q. Hu, J. Kim, D.M. Larkin, L. Auvil, et al. 2012. The yak genome and adaptation to life at high altitude. Nature Genetics 44 (8): 946-949. https://doi.org/10.1038/ng.2343.

Rauniyar, G.P., C.R. Upreti, R. Gavigan, and W.J. Parker. 2000. Constraints to sheep farming in Nepal: Development challenge for poverty alleviation. Asian Australasian Journal of Animal Sciences 13 (8): 1162-1172 https://doi.org/10 5713/ajas.2000.1162

Šoch, M., J. Brouček, and P. Šrejberová. 2011. Hematology and blood microelements of sheep in South Bohemia. Biologia 66 (1): 181-186. https:// doi.org/10.2478/s11756-010-0150-3.

Storz, J.F. 2007. Hemoglobin function and physiological adaptation to hypoxia in high-altitude mammals. Journal of Mammalogy 88 (1): 24-31 https://doi.org/ 10.1644/06-MAMM-S-199R1.1.

Storz, J.F. 2016. Hemoglobin-oxygen affinity in high-altitude vertebrates: Is there evidence for an adaptive trend? Journal of Experimental Biology 219 (20): 3190-3203. https://doi.org/10.1242/jeb.127134.

Storz, J.F., and H. Moriyama. 2008. Mechanisms of hemoglobin adaptation to high altitude hypoxia. High Altitude Medicine and Biology 9 (2): 148-157 https://doi.org/10.1089/ham.2007.1079.

Van Soest, P.J., J.B. Robertson, and B.A. Lewis. 1991. Methods for dietary fiber, neutral detergent fiber, and nonstarch polysaccharides in relation to animal nutrition. Journal of Dairy Science 74 (10): 3583-3597. https://doi.org/10.3168/ jds.S0022-0302 (91)78551-2.

Weber, R.E. 2007. High-altitude adaptations in vertebrate hemoglobins. Respiratory Physiology and Neurobiology 158: 132-142 https://doi.org/10.1016/ j.resp.2007.05.001.

Wilson, R.T. 1997. Animal genetic resources and domestic animal diversity in Nepal. Biodiversity and Conservation 6 (2): 233-251 https://doi.org/10.1023/A: 1018344103664.

Wu, T., X. Wang, C. Wei, H. Cheng, X. Wang, Y. Li, H. Zhao, P. Young, G. Li, and Z Wang. 2005. Hemoglobin levels in Qinghai-Tibet: Different effects of gender for Tibetans vs. Han. Journal of Applied Physiology 98 (2): 598-604 https://doi. org/10.1152/japplphysiol.01034.2002.

Xin, G.S., R.J. Long, X.S. Guo, J. Irvine, L.M. Ding, L.L. Ding, and Z.H. Shang. 2011. Blood mineral status of grazing Tibetan sheep in the northeast of the Qinghai-Tibetan Plateau. Livestock Science 136 (2-3): 102-107 https://doi.org/ 10.1016/.livsci.2010.08.007.

Yersin, A.G., W.E. Huff, L.F. Kubena, M.H. Elissalde, R.B. Harvey, D.A. Witzel, and L.E. Giroir. 1992. Changes in hematological, blood gas, and serum biochemical variables in broilers during exposure to simulated high altitude. Avian Diseases 36 (2): 189-196. https://doi.org/10.2307/1591489.

Zemp, M., J.W. Blum, H. Leuenberger, and N. Künzi. 1989. Influence of high altitude grazing on productive and physiological traits of dairy cows: II influence on hormones, metabolites and haematological parameters. Journal of Animal Breeding and Genetics 106 (4): 289-299.

\section{Publisher's Note}

Springer Nature remains neutral with regard to jurisdictional claims in published maps and institutional affiliations.

\section{Submit your manuscript to a SpringerOpen ${ }^{\circ}$ journal and benefit from:}

- Convenient online submission

- Rigorous peer review

- Open access: articles freely available online

- High visibility within the field

- Retaining the copyright to your article

Submit your next manuscript at $\boldsymbol{\nabla}$ springeropen.com 